\title{
Development of commercially viable plantations of Jatropha curcas L: case for promotion of its agricultural research
}

\section{Editorial}

The world's endless efforts to grow and expand its wealth have led to the burning of greater amounts of fossil fuel making energy supply and its security issues a topic of global interest. The growing concerns for the negative environmental implications of continued usage of excess fossil energy ignited the quest for alternative energy substitute. Biomass as a renewable energy resource is promising for developing and emerging economies and bio-diesel production from vegetable oils has been on the increase. Jatropha curcas L. has been identified as a candidate plant with great prospect for bio-diesel production as neither its seeds nor oil is edible by human or livestock. Jatropha is a multipurpose shrub which belongs to the Euphorbiaceae and has adapted to wide agro-climatic conditions. These qualities and a few others caused the shrub to emerge from obscurity to prominence in early 2000 .

The emergence of Jatropha curcas was surrounded with much hype; sweeping claims were made on the shrub's ability to grow on any soil type, its high drought tolerance capacity, ability to produce an average seed yield of 3.8 tons $\mathrm{ha}^{-1} \mathrm{y}^{-1}$ with little or no fertilizer input and a high seed oil content of $30-35 \%$. Along with these qualities is the eco-restoration potential of the shrub: ability to reclaim wastelands and check erosion, conserve and restore soil fertility and enhance socioeconomic development. ${ }^{1-3}$ All these hype, without any quantitative information backed by research, had raised enthusiasm for the shrub. This global enthusiasm backed by a desire for profit resulted in the springing up of mega plantations of Jatropha with companies like D1 Oils (www.d1plc.com), Viridas PLC (www. viridasplc.com) and Energem Resources Inc (www.energem.com) involved in this high risk venture $;{ }^{4}$ with an estimated 900,000 ha of land under cultivation globally to Jatropha by $2008 .^{5}$

In spite of the hype, there are several knowledge gaps that need to be bridged before emergence of the mega plantations. The refusal to allow this happen has currently led to unproductive Jatropha agriculture. For instance, our experience with a four year old Jatropha plantation with a spacing of $1.5 \mathrm{~m} * 1.5 \mathrm{~m}, 60 \mathrm{~kg}$ nitrogen $\mathrm{ha}^{-1}$ on an Alfisol or Alfisol related soil at Samaru in Nigeria, recorded seed yield of $698.7 \mathrm{~kg} \mathrm{ha}^{-1} \mathrm{y}^{-1}$ (the highest in four years) with average oil content of $37.25 \%$ to give an oil yield of $260.3 \mathrm{~kg}$ ha- $1 \mathrm{y}-1$. This is not viable from an economic view point as it is a far cry from the 1.2 tons ha $^{-1}$ oil yield accepted as commercially viable ${ }^{5}$ (Figure 1 ).

For several technical and economic reasons, the full potential of Jatropha curcas as a viable biodiesel alternative to fossil fuel is far from being realized. Unlike other major oilseed crops, there is currently no agronomic improved variety available in the market. Most seeds for plantation are sourced from the wild with wide variability in growth and yield. Experience has also shown that Jatropha is not different from other cultivated oilseed crops when it comes to managing soil, water, agrochemicals and biodiversity and the consequences of poor cultural practice are not different from those of the other oilseed
Volume I Issue 3 - 2014

\author{
Joshua O Ogunwole \\ Department of Crop Production and Protection, Federal \\ University, Dutsin-Ma, Nigeria
}

Correspondence: Joshua $O$ Ogunwole, Department of Crop Production and Protection, Faculty of Agriculture and Agricultural Technology, Federal University, Dutsin-Ma, PMB 500 I, Nigeria, Tel 234-805-822-0007, Email ogunwolejo@hotmail.com

Received: July 29, 2014 | Published: July 30, 2014

crops. Another area of agronomic challenge is the shrub's water footprint which has been reported to be 1.5times higher than soybean and 5times higher than ethanol from sugarcane and maize. ${ }^{6}$ All these emerging facts have dampened the initial enthusiasm for the shrub.

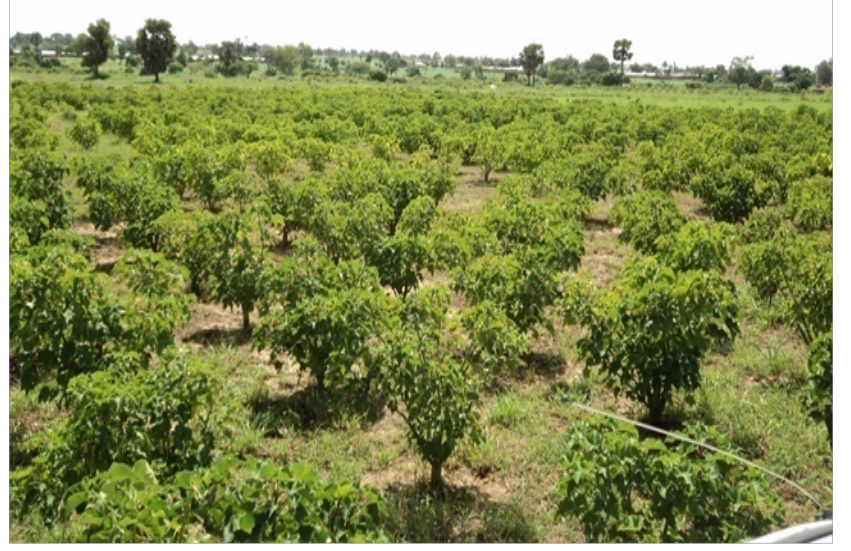

Figure I A 2-year old Jatropha plantation at Samaru, Nigeria.

Before the curtain is closed on Jatropha curcas however; agricultural research into its genetic improvement along with basic agronomic research to develop 'best bet' cultural practices for sustainable high productivity can be achieved. Currently, research results have shown that the shrub can improve quality of degraded soils. ${ }^{7,8}$ Therefore, integrating these technologies with sound policies and strengthening institutions could still ensure that future mega plantations of Jatropha curcas are commercially viable.

\section{Acknowledgements}

None.

\section{Conflict of interest}

The author declares no conflict of interest. 


\section{References}

1. Jongschaap REE, Corre WJ, Bindraban PS, et al. Claims and facts on Jatropha curcas L: Global Jatropha curcas evaluation, breeding and propagation programme. Plant Research International BV Report. $2007 ; 158: 42$

2. Peskett L, Slater R, Stevens C, et al. Biofuels, agriculture and poverty reduction. Overseas Development Institute. 2007;107:1-6.

3. Fairless D. Biofuel: the little shrub that could-maybe. Nature. 2007;449(7163): 652-655.

4. King AJ, He W, Cuevas JA, et al. Potential of Jatropha curcas as a source of renewable oil and animal feed. J Exp Bot. 2009;60(10):2897-2905.

5. Singh K, Patra DD, Singh B, Vet al. Jatropha curcas: a ten year story from hope to despair. Renewable and Sustainable Energy Reviews. 2014;35:356-360.
6. Gerbens-Leenes W, Hoekstra AY, van der Meer TH. The water footprint of bioenergy. Proc Nat Acad Sci USA. 2009;106(25):10219-10223.

7. Ogunwole JO, Patolia JS, Chaudhary DR, et al. Improvement of the quality of a degraded entisols with Jatropha curcas L. under Indian semi arid condition. Article No. 10. In: Jatropha curcas L. (Agronomy and Genetics), Proceedings of a FACT Seminar, March 26-28, Wageningen, The Netherlands: FACT Foundation Publishers; 2007.

8. Ogunwole JO, Chaudhary DR, Ghosh A, et al. Contribution of Jatropha curcas to soil quality improvement in a degraded Indian entisol. Acta Agriculturae Scandinavica, Section B-Soil \& Plant Science. 2008;58(3):245-251. 